\title{
MATHEMATICAL LEARNING MOTIVATION OF SUBMISSION AND REDUCTION OF PARTICIPANTS IN PRIMARY SCHOOL USING REALISTIC MATHEMATICS EDUCATION (RME)
}

\author{
Dodi Andriansah $^{1}$, Mia Yusmianti ${ }^{2}$, Anugrah Ramadhan Firdaus ${ }^{3}$ \\ ${ }^{1}$,SD Negeri Manggah, \\ ${ }^{2}$ SD Negeri Pareangkolot \\ ${ }^{3}$ IKIP Siliwangi \\ 19andriansahdodi@gmail.com, ${ }^{2}$ yusmiantimia@gmail.com, ${ }^{3}$ arf432@gmail.com
}

\begin{abstract}
This study aims to explain the application of realistic mathematics education in addition and subtraction mathematics learning in class III of SDN 1 Sudimampir, one of the low motivation of students to learn mathematics addition and subtraction is caused by learning activities that are more teacher-centered, so students are less actively involved in the learning process and result in monotonous learning activities in the classroom. Based on the above problems, improvements can be made to increase motivation to learn mathematics using realistic mathematics education. population and sample in the study focused on class III students, the method used in this study was the experimental method. The data collection technique is to provide learning and working on the problem, then grouping values based on the results of student performance in working on mathematical questions, arranged based on group distribution data for more specific value distribution into the mean median mode and graphs in order to find out the results of applying realistic mathematical methods education is expected to increase students 'motivation to learn mathematics, from the study there was a significant increase in the mean score of students' scores in mathematics learning addition and subtraction, namely $\pm 67,57$.
\end{abstract}

Keywords: learning motivation, summation of reduction, realistic mathematics education method

\begin{abstract}
Abstrak
Penelitian ini bertujuan menjelaskan penerapan metode realistic mathematics education pada pembelajaran matematika penjumlahan dan pengurangan pada kelas III SDN 1 Sudimampir, salah satu rendahnya motivasi siswa untuk belajar matematika penjumlahan dan pengurangan disebabkan karena kegiatan pembelajaran yang lebih berpusat pada guru, sehingga siswa kurang terlibat secara aktif dalam proses pembelajaran serta berakibat monotonnya kegiatan pembelajaran di dalam kelas. Berdasarkan permasalahan di atas dapat dilakukan perbaikan untuk meningkatkan motivasi belajar matematika menggunakan realistic matematics education. populasi dan sampel dalam penelitian difokuskan pada siswa kelas III, metode yang digunakan dalam penelitian ini adalah metode eksperimen. Teknik pengumpulan data yaitu dengan memberikan intrusksi pembelajaran dan mengerjakan soal, selanjutnya dilakukan pengelompokan nilai berdasarkan hasil kinerja siswa dalam mengerjakan soal matematika, disusun berdasarkan data distribusi kelompok untuk pembagian nilai lebih spesifik kedalam mean median modus dan grafik agar dapat mengetahui hasil dari penerapan metode realistic matematics education yang diharapkan dapat meningkatkan motivasi belajar matematika siswa, dari penelitian tersebut terdapat peningkatan yang signifikan yaitu rata-rata skor nilai siswa dalam pembelajaran matematika penjumlahan dan pengurangan yakni $\pm 67,57$.
\end{abstract}

Kata Kunci: motivasi belajar, penjumlahan pengurangan, metode realistic matematics education.

\section{INTRODUCTION}

In the activities of the learning process, interest / motivation is a very important aspect, this is because (a) motivation (interest) encourages a student in his learning activities, (b) motivation (interest) actions are voters of the type of activity- activities where a person desires 
to do it, and (c) motivation (interest) also gives guidance on behavior (Rusyan, et al., 1989: 9697). Sardiman, (2004: 83) suggests the characteristics of someone who has a high interest (motivation) in the form of;

1. Diligent in facing the task (can work continuously for a long time, never stop before it's finished),

2. Resilient face difficulties (not desperate),

3. Showing interest in various problems,

4. Prefer to work independently,

5. Quickly get bored on routine tasks (things that are mechanical, repetitive so that they are less creative),

6. Can maintain his opinion (if you are sure of something),

7. It is not easy to let go of what is believed, and

8. Nice to find and solve problems.

The low learning outcomes of mathematics because most students are less enthusiastic about receiving it. Students are more passive, reluctant, afraid or embarrassed to express opinions not infrequently students feel less capable of learning mathematics because mathematics is considered difficult, frightening, even some of them will hate it so mathematics is considered a scourge by them. This causes students to be afraid of mathematics.

The low ability of the teacher to create situations that bring students interested in mathematics, weak mastery of the material by the teacher, lack of tools or infrastructure in learning in the classroom, and the influence of the surrounding environment that negatively affects the students themselves. This is according to what was conveyed by Heman Hudoyo (Rosyanda, 2002: 3) that in the classroom the teacher is not able to create situations that allow reciprocal communication in mathematics lessons and often occur unconsciously the teacher creates situations that inhibit communication.

From several learning models, researchers chose an interesting learning model that could trigger student communication, namely the Realistic Mathematics Education (RME) approach in learning third grade students at SDN 1 Sudimampir.

RME as a new approach in learning mathematics. RME invites students to be able to like mathematics by paying attention to students how to learn mathematics through direct experience to the environment which shows students undergoing their own processes similar 
to the creation of mathematics through contextual mathematical activities namely student mindset activities developed from concrete things to things - abstract thing.

Learning mathematics with realistic models is basically the use of reality and environment that students understand to accelerate the process of learning mathematics so as to achieve the goals of mathematics education better than the past. The reality in question is things - real things that can be observed and understood by students by imagining, while the environment is where students are (Soejadi, 2003: 180).

To increase motivation to learn mathematics, one of the efforts we can do is understand how our students learn. Providing the right stimulus can increase students' confidence and motivate them during the learning process (Firdaus, 2018). the important teaching and learning process is the mastery of the climate in the classroom so that it creates a pleasant atmosphere that makes students' interest in learning increase, such as paying attention to the lessons given by the teacher, actively asking questions about what is not clear, expressing ideas actively, actively conducting experiments, actively working on questions given by the teacher in front of the class.

Therefore a teacher's creativity in teaching mathematics is an important factor so that mathematics becomes a fun and interesting subject in the classroom. Creativity is not a talent, but can be learned and must be trained. (Ahmad Rohani, 2004: 6). It has been realized that the quality of education is very dependent on the quality of the teacher and the quality of the learning. In learning mathematics also found a variety of problems as follows:

1. Students rarely ask questions, even though teachers often ask students to ask if there are things that don't understand.

2. The ability to count students in mathematics learning is very low.

3. Low student courage in answering questions.

Having identified the students in the class turned out to have low self-esteem because students have a fear of ridicule from other friends if the answer is wrong, in addition, students feel afraid when making mistakes will be scolded by the teacher so they are reluctant to answer questions in front of the class or give opinions during activities learning takes place.

To anticipate the problem so that it is not sustainable, it makes the teachers keep trying to compile and define various methods that vary. Presentation of various teaching methods and their application in teaching mathematics is so that students, teachers, have extensive knowledge of methods and have the skills to apply them. One method that will be applied is 
learning mathematics by learning RME (Realistic Mathematics Education) to increase the motivation to learn mathematics in addition and subtraction of third-grade students of SDN 1 Sudimampir.

Previous research relevant to researchers was conducted by Ita Nurakshani in 2015 with the title "Improving Student Motivation Through Realistic Mathematics Education (RME) Strategies in Mathematics Subjects in Class III Kecik 3 Elementary School Students 2014/2015 Academic Year" classified as low before the implementation of Realistic Mathematics Education or RME strategies. It was evident in the observation on pre-cycle which showed that class III learning motivation was $21.14 \%$, then in cycle 1 it increased to $42.72 \%$, and in cycle 2 it increased to $92.30 \%$. So that on the second-semester students' learning motivation has reached the expected level of more than $80 \%$ and produces a conclusion that the use of Realistic Mathematics Education (RME) strategies can increase student learning activeness.

Therefore, in this case, the authors propose the use of models in each mathematics learning is realistic or real things to increase students' interest in learning mathematics. And therefore the author chose the research title "Increasing Mathematics Learning Motivation Addition and Reduction of Class III Students in SDN 1 Sudimampir Using Realistic Mathematics Education (RME)"

\section{METHOD}

The research method is essentially a series of research activities based on basic assumptions, philosophical and ideological views. The use of appropriate methods can help solve problems in research.

Based on the objectives and problems studied, this research included quasiexperimental research with the One Group Pre-Test Design Post-Test approach. The procedure in this experimental study begins with giving the initial test to see the students 'initial abilities, then students are given treatment by applying the Realistic Mathematics Education method and then the final test is held to determine the students' abilities after treatment. This method is used because the researcher wants to know the effect of the Realistic Mathematics Education method on the motivation to learn mathematics in SDN 1 Sudimampir students.

\section{RESULTS AND DISCUSSION}

\section{Results}


In class III mathematics learning, students are instructed to look at the surrounding environment to combine addition and subtraction based on their ideas and ideas, the learning steps are as follows:

1. The teacher divides students into several groups.

2. Each group determines the group leader;

3. The teacher explains the learning material before applying the rme method;

4. Before explaining the method each group is given a picture media that has been provided by the teacher.

5. Before learning takes place the teacher has prepared supporting facilities.

6. Determine the time limit used;

7. Determine the rules of the game used in rme;

8. Providing opportunities for participants to convey their ideas;

9. The group leader writes each idea put forward by group members;

10. Each group groups similar ideas;

11. Conduct a discussion of ideas; and

12. Summing up the conversation.

The final stage after applying the rme method students was assigned to fill out individual evaluation tests. The test consists of 5 filling questions in the pretest and posttest stages, there are results of data received from the experimental class, which amount to 28 students. Aspects assessed in mathematics learning are 5 questions.

The data obtained were then tested for significance to determine the success of the research that had been carried out.

Table 1. Scores of Summing and Final Tests for Addition and Subtraction

\begin{tabular}{ccc}
\hline Learners & Pre-test $(\mathbf{X})$ & $\begin{array}{c}\text { Post-test } \\
(\mathbf{Y})\end{array}$ \\
\hline 1 & 53 & 60 \\
2 & 64 & 70 \\
3 & 45 & 60 \\
4 & 55 & 65 \\
5 & 53 & 55 \\
6 & 62 & 72 \\
7 & 47 & 55 \\
8 & 56 & 60 \\
9 & 62 & 75
\end{tabular}




\begin{tabular}{lll}
10 & 65 & 70 \\
11 & 63 & 67 \\
12 & 55 & 60 \\
13 & 70 & 82 \\
14 & 65 & 73 \\
15 & 64 & 70 \\
16 & 55 & 65 \\
17 & 45 & 56 \\
18 & 55 & 67 \\
19 & 65 & 73 \\
20 & 65 & 70 \\
21 & 53 & 67 \\
22 & 54 & 63 \\
23 & 63 & 65 \\
24 & 67 & 67 \\
25 & 56 & 68 \\
26 & 65 & 80 \\
27 & 63 & 75 \\
28 & 65 & 82 \\
\hline
\end{tabular}

Table 2. Calculation of class III Mathematics Summation and Subtraction learning data analysis

\begin{tabular}{cccc}
\hline No & Data & X (pre-tes $)$ & Y(post-tes $)$ \\
\hline 1 & N & 28 & 28 \\
2 & Highest score & 70 & 82 \\
3 & Lowest score & 45 & 55 \\
4 & Mean & 58.93 & 67.57 \\
5 & Median & 62 & 67 \\
6 & Mod & 65 & 60 \\
7 & Std. Deviasi & 6.853 & 7.466 \\
8 & Correlation & 0.816 & 0.816 \\
9 & Variation & 46.958 & 55.735 \\
\hline
\end{tabular}

\section{Discussion}

Based on research in class III SDN 1 Sudimampir in addition and subtraction learning using the Realistic Mathematics Education method, it can be seen that in the initial test there was the highest score of 70 , the lowest score was 45 , the average value was 58.93 , the middle score was 65 , the dominant value was 65 , the standard deviation 6,853 , and variance of 46,958 . Whereas in the final test (post-test) there is the highest score of 82, the lowest score is 55 , the average value is 67.57 , the middle score is 67 , the dominant value is 60 , the standard deviation is 7.466 , and the variance is 55,735 . 
The calculation results show that the average pre-test is 58.93 and the variance is 46,958 and the post-test average is 67.53 , the variation is 55,735. The correlation between the pre-test and post-test scores is 0.816 which means that there is a high positive relationship between the pre-test and post-test. The results of this study prove that the success of learning depends on students and teachers, the addition and reduction of students will not succeed if students do not respond to instructional instructions given by the teacher, and vice versa, the teacher cannot implement addition and subtraction learning without using creative methods and media to achieve success in learning.

\section{CONCLUSION}

Based on the data analysis and discussion that has been described previously, it can be concluded that the learning of Addition and Subtraction in class III SDN 1 Sudimampir using the Realistic Mathematics Education method included in the excellent category there is an average pre-test value of 58.93 and an average post-test score 67.57. Through the Realistic Mathematics Education method, students can train their mindset to express ideas, ideas together to exchange arguments with their group friends in addition and subtraction. With Realistic Mathematics Education students are more enthusiastic, creative, and discussion becomes fun in writing explanatory texts because they discuss directly with the help of audiovisual media. This indicates that learning uses the Realistic Mathematics Education method influential in increasing the motivation to learn mathematics in third-grade students at SDN 1 Sudimampir.

\section{REFERENCES}

Asikin, M. (2001). Realistic Mathematics Education (RME): Prospek dan Alternatif Pembelajarannya. Makalah disajikan pada Seminar Nasional Matematika di UNNES Semarang. Tanggal: 27 Agustus 2001.

Firdaus, A.R. (2018). Application Of Everyone Is A Teacher Here Learning Model To Improve Self Confidence Students. Journal PrimaryEdu. IKIP Siliwangi Bandung

Hudoyo, H. (1988). Mengajar Belajar Matematika. Jakarta: Dirjen Dikti Depdikbud.

Rohani, A. (2004). Pengelolaan Pengajaran. Jakarta. PT. Rineka Cipta. 
Rusyan, dkk., (1989). Pendekatan Dalam Proses Belajar Mengajar, Bandung : Remaja Karya.

Sardiman. (2004). Interaksi dan Motivasi Belajar Mengajar. Jakarta : Raja Grafindo Persada.

Soejadi. (2003). Kiat Pendidikan Matematika di Indonesia. Jakarta : Depdikdas. 